\title{
Chlorophyll a fluorescence in saccharine sorghum irrigated with saline water
}

\author{
Danilo R. Monteiro ${ }^{1}$, Hidelblandi F. de Melo ${ }^{1}$, Cintia M. T. Lins ${ }^{1}$, \\ Pablo R. M. Dourado ${ }^{1}$, Hugo R. B. Santos ${ }^{1} \&$ Edivan R. de Souza $^{1}$
}

${ }^{1}$ Universidade Federal Rural de Pernambuco. Recife, PE. E-mail: danilor.monteiro1@gmail.com (Corresponding author) - ORCID: 0000-0001-9989-
6342; hidelfarias@gmail.com - ORCID: 0000-0002-6905-1143; cintia_lins2@hotmail.com - ORCID: 0000-0001-7957-3458; rugerodm@hotmail.com
- ORCID: 0000-0003-3902-8791; hugobentzen@hotmail.com - ORCID: 0000-0001-8020-537X; edivanrs@hotmail.com - ORCID: 0000-0002-2442-7266

\section{Key words:}

salinity

photosynthetic pigments

photochemical efficiency

\begin{abstract}
A B S T R A C T
Soil salinity directly affects plants, interfering in the emission of fluorescence, and promoting the degradation of photosynthetic pigments. Thus, estimating the damage to the photosynthetic apparatus caused by saline water is an important tool to detect abiotic stresses. For this purpose, sorghum plants were cultivated in a greenhouse and irrigated with two water sources ( $\mathrm{NaCl}$ and salt mixture) with six levels of electrical conductivity (EC) $\left(0,2.5,5,7.5,10\right.$, and $\left.12.5 \mathrm{dS} \mathrm{m}^{-1}\right)$, forming a $6 \times 2$ factorial in randomized blocks with four repetitions. At 60 days after sowing, the photosynthetic pigments were quantified, the chlorophyll a fluorescence parameters (initial fluorescence $\left[\mathrm{F}_{0}\right]$; variable fluorescence $\left[\mathrm{F}_{\mathrm{v}}\right]$; maximum fluorescence $\left[\mathrm{F}_{\mathrm{m}}\right]$; quantum efficiency of photosystem II - PSII $\left[\mathrm{F}_{\mathrm{v}} / \mathrm{F}_{\mathrm{m}}\right]$; electron flux per reaction center $\left[\mathrm{ET}_{0} / \mathrm{CR}\right]$; quantum energy dissipation $\left[\mathrm{DI}_{0} / \mathrm{CR}\right]$ and quantum yield for heat dissipation $\left[\varphi \mathrm{D}_{0}\right]$ ) were evaluated. The photosynthetic pigments were decreased with an increase in the salinity of the irrigation water, and were more expressive at higher electrical conductivities. With the wear on the photosynthetic apparatus by the increase in salinity, a reduction in the emission of the chlorophyll a fluorescence was observed, pointing to a possible photoinhibition of photosystem II.
\end{abstract}

Palavras-chave:

salinidade

pigmentos fotossintéticos

eficiência fotoquímica

\section{Fluorescência da clorofila a em sorgo sacarino irrigado com água salina}

\section{R E S U M O}

A salinidade do solo afeta diretamente os vegetais interferindo na emissão da fluorescência, além de promover a degradação dos pigmentos fotossintéticos. Assim, estimar o dano no aparato fotossintético provocado por águas salinas é uma ferramenta para detectar o nível de estresses abióticos. Para tanto, plantas de sorgo sacarino foram cultivadas em ambiente protegido e irrigadas com duas fontes de água ( $\mathrm{NaCl}$ e Mistura de sais) com seis níveis de condutividade elétrica - CE $\left(0 ; 2,5 ; 5 ; 7,5 ; 10\right.$ e $\left.12,5 \mathrm{dS} \mathrm{m}^{-1}\right)$ formando um fatorial de $6 \times 2$ em blocos ao acaso com 4 repetições. Aos 60 dias após a semeadura, os pigmentos fotossintéticos foram quantificados, além de avaliar os parâmetros da fluorescência da clorofila a: fluorescência inicial $\left(\mathrm{F}_{0}\right)$; fluorescência variável $(\mathrm{Fv})$; fluorescência máxima $\left(\mathrm{F}_{\mathrm{m}}\right)$; eficiência quântica do fotossistema II - PSII $\left(\mathrm{F}_{\mathrm{v}} / \mathrm{F}_{\mathrm{m}}\right)$; fluxo de transporte de elétrons por centro de reação (ET/CR); energia dissipada por centro de reação ( $\left.\mathrm{DI}_{0} / \mathrm{CR}\right)$ e rendimento quântico da energia dissipada $\left(\varphi \mathrm{D}_{0}\right)$. Os pigmentos fotossintéticos apresentaram reduções com o aumento da salinidade da água de irrigação, sendo mais expressivas nas maiores condutividades elétricas. Com o desgaste do aparato fotossintético pelo aumento da salinidade, observou-se a redução na emissão da fluorescência da clorofila a, apontando para possível fotoinibição do fotossistema II. 


\section{INTRODUCTION}

In semi-arid regions, besides the low water availability and high temperatures, another important factor is the salinity; sorghum is moderately tolerant to this stressing agent (Nabati et al., 2013). This is probably associated with mechanisms such as the control of sodium accumulation in leaves (Deinlein et al., 2014), osmotic adjustment associated with the accumulation of soluble sugars (Yamaguchi \& Blumwald, 2005), and maintenance of the synthesis and protection of pigments, such as chlorophyll (Ashraf \& Harris, 2013).

According to Tavakkoli et al. (2011), the main ionic constituents of soluble salts in the soil are sodium, calcium, magnesium, and chloride, as well as carbonates and bicarbonates. The action of these salts is directly linked to injuries in the function of photosystem II (PSII) (Ambede et al., 2012). Under stressful environmental conditions, especially in plants under the influence of saline stress, the enzyme chlorophyllase correlates with the degradation of photosynthetic pigments (Neves \& Spat, 2013).

Generally, the estimation of chlorophyll a fluorescence is used as a way to monitor the electron transfer in the face of environmental adversities, considering that this technique is fast, precise, and non-destructive (Maxwell \& Johnson, 2000). Thus, the study of physiological parameters, such as pigment contents and chlorophyll a fluorescence, are important in the determination of the effects of osmotic and water conditions on photosynthetic efficiency in plants (Melo et al., 2017a, b).

Therefore, the objective of this study was to evaluate the foliar photosynthetic pigment contents and chlorophyll a fluorescence in sorghum plants subjected to irrigation with saline solutions of different ionic compositions and increasing levels of electrical conductivity.

\section{Material AND Methods}

The experiment was conducted in a greenhouse located at the Federal Rural University of Pernambuco, Recife Campus, Brazil, from December 2015 to February 2016, with an experimental period of 60 days. During the conduction of the experiment, the mean values of relative humidity and temperature were $64.5 \%$ and $31{ }^{\circ} \mathrm{C}$, respectively, as monitored by datalogger.

The soil used came from the rural area of the city of Pesqueira $\left(08^{\circ} 21^{\prime} 28^{\prime \prime} \mathrm{S}\right.$ and $\left.36^{\circ} 41^{\prime} 47^{\prime \prime} \mathrm{W}\right)$, located in the semi-arid region of the northeast, in the Upper Ipanema basin, in the state of Pernambuco, Brazil. The collection was carried out in the $0-30 \mathrm{~cm}$ layer, in a soil classified as Neossolo Flúvico (Fluvent), according to EMBRAPA (2013). The soil was air dried, decanted, homogenized, and passed through a $4 \mathrm{~mm}$ sieve in order to preserve the micro-aggregates.

In order to characterize the chemical properties of the soil (Table 1), the $\mathrm{pH}$ in the water was determined in the proportion of 1:2.5 (soil:water); $\mathrm{Ca}^{2+}$ and $\mathrm{Mg}^{2+}$ were extracted in $1 \mathrm{M} \mathrm{KCl}$ solution and titrated with EDTA, and $\mathrm{Na}^{+}$and $\mathrm{K}^{+}$ were extracted by Mehlich-1 and quantified in a flame emission photometer. The analysis was according to the methodology proposed by EMBRAPA (1997). The cation exchange capacity (CEC), the sum of bases (SB), and the exchangeable sodium percentage (ESP) were calculated from the values obtained in the exchange complex. The saturation extract was obtained from the saturation paste (Richards, 1954), and its electrical conductivity and $\mathrm{pH}$ were measured.

For the physical characterization, the granulometry and water dispersed clay (WDC) were determined in the air dried soil using the the densimeter method, which measures bulk density and particle density (EMBRAPA, 1997) (Table 1).

Sorghum plants of IPA 2502 were cultivated in pots $(8 \mathrm{~L})$ filled with Neossolo Flúvico (Fluvent) soil, and irrigation occurred daily, maintaining the soil moisture at $80 \%$ of the soil field capacity. The moisture control was performed by daily weighing, and replacement of evapotranspirated water. Two solutions were used (Table 2) with six levels of electrical conductivity ( 0 , distilled water; $2.5 ; 5 ; 7.5 ; 10$; and $12.5 \mathrm{dS} \mathrm{m}^{-1}$ ). The solution for the mixture of salts was elaborated according to the ionic proportions of water collected from the artesian wells used for irrigation in the region of soil collection.

The treatment of $12.5 \mathrm{dS} \mathrm{m}^{-1}$ was disregarded, since the experimental units related to it did not resist until the end of the experiment due to the high salt contents of the solutions.

The fluorescence parameters of chlorophyll a (initial fluorescence $\left[\mathrm{F}_{0}\right]$, variable fluorescence $\left[\mathrm{F}_{\mathrm{v}}\right]$, maximum fluorescence $\left[\mathrm{F}_{\mathrm{m}}\right]$, quantum efficiency of PSII $\left[\mathrm{F}_{\mathrm{v}} / \mathrm{F}_{\mathrm{m}}\right]$, electron flow per reaction center $\left[\mathrm{ET}_{0} / \mathrm{CR}\right]$, energy $\left[\mathrm{DI}_{0} / \mathrm{CR}\right]$, and quantum energy dissipation $\left.\left[\varphi \mathrm{D}_{0}\right]\right)$ were measured at 60 days after sowing (DAS) with the aid of the FluorPen F100 fluorometer (Photon Systems Instruments, Drasov, Czech Republic). The measurements were performed on the second fully expanded and healthy upper leaf after the period of

Table 1. Chemical and physical characterization of the Neosolo Flúvico (Fluvent) soil used to fill the pots in the greenhouse experiment

\begin{tabular}{|c|c|c|c|c|c|c|c|c|c|c|c|}
\hline \multicolumn{12}{|c|}{ Chemical parameters } \\
\hline \multicolumn{2}{|c|}{ Saturation extract } & \multirow[b]{2}{*}{$\mathrm{pH}_{\mathrm{H} 20}$} & \multicolumn{9}{|c|}{ Exchangeable cations } \\
\hline $\begin{array}{c}\text { EC } \\
\left(\mathrm{dS} \mathrm{m}^{-1}\right)\end{array}$ & $\mathrm{pH}_{\mathrm{es}}$ & & \multicolumn{7}{|c|}{$\left(\mathrm{cmol}_{\mathrm{c}} \mathrm{kg}^{-1}\right)$} & $\begin{array}{c}\mathrm{T} \\
(\mathrm{pH} 7.0)\end{array}$ & $\begin{array}{l}\text { ESP } \\
\text { (\%) }\end{array}$ \\
\hline 3.2 & 7.9 & 6.5 & 4.35 & 2.73 & 1.48 & 0.77 & 9.33 & 1.43 & 0.0 & 10.76 & 13.75 \\
\hline \multicolumn{12}{|c|}{ Physical parameters } \\
\hline \multicolumn{2}{|c|}{ Sand } & Silt & Clay & WDC & BD & PD & TP & FD & DD & FC & PWP \\
\hline \multicolumn{5}{|c|}{$\left(\mathrm{g} \mathrm{kg}^{-1}\right)$} & \multicolumn{2}{|c|}{$\left(\mathrm{kg} \mathrm{dm}^{-3}\right)$} & \multicolumn{3}{|c|}{ (\%) } & \multicolumn{2}{|c|}{$\left(g^{-1}\right)$} \\
\hline 315 & 163 & 378 & 144 & 100 & 1.28 & 2.52 & 49.15 & 30.56 & 69.44 & 0.26 & 0.05 \\
\hline
\end{tabular}

Chemical parameters: EC - Electrical conductivity; $\mathrm{SB}-$ Sum of exchangeable bases $(\mathrm{SB}=\mathrm{Ca}+\mathrm{Mg}+\mathrm{Na}+\mathrm{K}) ; \mathrm{T}-$ Cation exchange capacity $(\mathrm{CEC}=\mathrm{SB}+(\mathrm{Al}+\mathrm{H})) ; \mathrm{ESP}-\mathrm{Exchangeable}$ sodium percentage $\left(\mathrm{ESP}=\left(100 * \mathrm{Na}^{+}\right) / \mathrm{CTC}\right)$. Physical parameters: WDC - Water dispersed clay; BD - Bulk density; PD - Particle density; TP - Total porosity; FD - Flocculation degree; DD - Dispersion degree; FC - Water content at field capacity; PWP - Water content at the permanent wilting point 
Table 2. Quantity of salts $\left(\mathrm{g} \mathrm{L}^{-1}\right)$ required for the formulation of saline solutions, in order to obtain the electrical conductivities of the treatments

\begin{tabular}{|c|c|c|c|c|c|c|c|}
\hline \multirow{2}{*}{$\begin{array}{c}\text { CE } \\
\left(\mathrm{dS} \mathrm{m}^{-1}\right)\end{array}$} & \multirow{2}{*}{$\mathrm{NaCl}$} & \multicolumn{6}{|c|}{ Mixture of salts } \\
\hline & & $\mathrm{NaCl}$ & $\mathrm{CaCl}_{2}$ & $\frac{\mathrm{Ca}\left(\mathrm{NO}_{3}\right)_{2}}{\left(\mathrm{~g} \mathrm{~L}^{-1}\right)}$ & $\mathrm{MgCl}_{2}$ & $\mathrm{MgSO}_{4}$ & $\mathrm{KCl}$ \\
\hline 0 & - & - & - & - & - & - & - \\
\hline 2.5 & 1.203 & 0.751 & 0.229 & 0.079 & 0.258 & 0.402 & 0.069 \\
\hline 5.0 & 2.773 & 1.728 & 0.528 & 0.181 & 0.593 & 0.925 & 0.159 \\
\hline 7.5 & 4.461 & 2.950 & 0.901 & 0.309 & 1.012 & 1.580 & 0.272 \\
\hline 10.0 & 6.397 & 4.256 & 1.300 & 0.445 & 1.460 & 2.279 & 0.392 \\
\hline 12.5 & 8.372 & 5.842 & 1.785 & 0.612 & 2.005 & 3.129 & 0.538 \\
\hline
\end{tabular}

adaptation to the dark for $30 \mathrm{~min}$, for total oxidation of the PSII reaction center.

The chemical extraction and determination of the chlorophyll a, b, and carotenoid contents followed the methodology described by Lichtenthaler \& Buschmann (2001).

The experiment was carried out in randomized block in a $6 \times 2$ factorial with four replications, totaling 48 experimental units. The data were submitted to analysis of variance, with the adjustments of regression equations, and the means were compared by Tukey's Test $(\mathrm{p}<0.05)$.

\section{Results AND Discussion}

There was significant interaction $(\mathrm{p}<0.01)$ between the sources of salts and the increasing levels of electrical conductivity (Table 3 ). The chlorophyll a (Chla) leaf contents decreased, except for in the treatment with $2.5 \mathrm{dS} \mathrm{m}^{-1}$, which presented an increase of $28.25 \%$, for the solution mixture of salts, in relation to the control. The highest decreases were observed for the electrical conductivity of $10 \mathrm{dS} \mathrm{m}^{-1}(70.66 \%)$, in the $\mathrm{NaCl}$ solution, and for the electrical conductivity of $7.5 \mathrm{dS} \mathrm{m}^{-1}(68.14 \%)$ for the mixing solution of salts.

For the $\mathrm{NaCl}$ solution, more precisely, from EC $2.5 \mathrm{dS} \mathrm{m}^{-1}$, the chlorophyll $b$ (Chlb) and carotenoid contents decreased with the increase in the electrical conductivities. However, in the salt mixing solution at $2.5 \mathrm{dS} \mathrm{m}^{-1}$, the highest value was observed for both parameters (Table 3 ).

In the ratio Chla:Chlb leaf content, a significant difference was observed between the factors (salt source and level of electrical conductivity) at $\mathrm{p}<0.01$ (Table 3 ). However, from the salt sources, a significant difference only occurred at an EC of $10 \mathrm{dS} \mathrm{m}^{-1}$. The highest decrease (50.19\%), when compared to the control, was observed at an EC of $10 \mathrm{dS} \mathrm{m}^{-1}(\mathrm{NaCl})$.

Photosynthetic pigments are responsible for capturing the photons of light and transmitting energy to the reaction centers.
Under stress conditions, such pigments are directly affected as long as stress progresses, and biochemical changes may limit photosynthetic activity more directly, resulting in oxidative damage to cells (Viana et al., 2002). With an increase in $\mathrm{NaCl}$ in the irrigation water, the activation of the chlorophyllase enzyme occurs in stressed plants, and is the main factor related to reductions in the contents of photosynthetic pigments (Neves \& Spat, 2013).

Lacerda et al. (2003) studied the salinity tolerance in two contrasting sorghum genotypes, and observed a 52\% reduction in chlorophyll content for the sensitive genotype (CSF18) and $27 \%$ reduction for the salinity tolerant genotype (CSF20), when submitted at $100 \mathrm{mM} \mathrm{NaCl}$. In sugarcane plants submitted to irrigation with a $200 \mathrm{mM}$ saline solution of $\mathrm{NaCl}$, there was a decrease in the levels of Chla, Chlb, and carotenoids by 68.9, 70 , and $49.8 \%$, respectively, compared to the levels in the $0 \mathrm{mM}$ concentration (Barreto et al., 2013). Neves \& Spat (2013) found reductions of more than $50 \%$ in rice cultivars irrigated with saline solutions with concentrations ranging from 0 to $150 \mathrm{mM} \mathrm{NaCl}$.

In a study of six rice cultivars under stress conditions, Cancellier et al. (2011) found a reduction in the chlorophyll $\mathrm{a} / \mathrm{b}$ ratio. These authors considered that cultivars that presented lower chlorophyll $\mathrm{a} / \mathrm{b}$ relations were more efficient in the capture of light, since this decrease is not due to the reduction in Chla. This was differently observed in the present study, where Chla reductions were higher than those in Chlb.

No significant difference was observed between the salt sources; however, a significant difference in the increasing levels of electrical conductivity $(\mathrm{p}<0.01)$ was observed. The $\mathrm{F}_{0}$ of sorghum plants presented an increase with the increase in electrical conductivity of the irrigation water (Figure 1A). An electrical conductivity of $10 \mathrm{dS} \mathrm{m^{-1 }}$ was the most significant, with an increase of $82.23 \%$ compared to that of the control.

The initial fluorescence explains the fluorescence emission when the primary electron acceptor quinone (QA) of

Table 3. Leaf content of chlorophyll a, b, and carotenoids in sorghum irrigated with saline solutions with increasing electrical conductivity (EC) at 60 days after sowing (DAS)

\begin{tabular}{|c|c|c|c|c|c|c|c|c|}
\hline \multirow{3}{*}{$\begin{array}{c}E C \\
\left(\mathrm{dS} \mathrm{m}^{-1}\right)\end{array}$} & \multicolumn{2}{|c|}{ Chlorophyll a } & \multirow{2}{*}{\multicolumn{2}{|c|}{ Chlorophyll b }} & \multirow{2}{*}{\multicolumn{2}{|c|}{ Ratio Chla/Chlb }} & \multirow{2}{*}{\multicolumn{2}{|c|}{$\begin{array}{c}\text { Carotenoid } \\
\left(\mathrm{mg} \mathrm{g}^{-1}\right)\end{array}$}} \\
\hline & \multicolumn{2}{|c|}{$\left(\mathrm{mg} \mathrm{g}^{-1}\right)$} & & & & & & \\
\hline & $\mathrm{NaCl}$ & MS & $\mathrm{NaCl}$ & MS & $\mathrm{NaCl}$ & MS & $\mathrm{NaCl}$ & MS \\
\hline 0 & $1.645 \mathrm{aA}$ & $1.319 \mathrm{aAB}$ & $0.370 \mathrm{aA}$ & $0.349 \mathrm{aBC}$ & $4.439 \mathrm{aA}$ & $3.783 \mathrm{aA}$ & $0.607 \mathrm{aA}$ & $0.503 \mathrm{bB}$ \\
\hline 2.5 & $1.475 \mathrm{aA}$ & $1.692 \mathrm{aA}$ & $0.406 \mathrm{bA}$ & $0.648 \mathrm{aA}$ & $3.632 \mathrm{aA}$ & $2.611 \mathrm{aB}$ & $0.519 \mathrm{bAB}$ & $0.659 \mathrm{bA}$ \\
\hline 5.0 & $1.221 \mathrm{aAB}$ & $1.291 \mathrm{aAB}$ & $0.341 \mathrm{Aa}$ & $0.361 \mathrm{aB}$ & $3.581 \mathrm{aA}$ & $3.574 \mathrm{aA}$ & $0.510 \mathrm{aAB}$ & $0.504 \mathrm{aB}$ \\
\hline 7.5 & $0.893 \mathrm{aB}$ & $0.420 \mathrm{bC}$ & $0.284 \mathrm{Aa}$ & $0.158 \mathrm{aC}$ & $3.143 \mathrm{aAB}$ & $2.646 \mathrm{aB}$ & $0.436 \mathrm{aBC}$ & $0.330 \mathrm{bC}$ \\
\hline 10.0 & $0.483 \mathrm{bC}$ & $1.005 \mathrm{aB}$ & $0.218 \mathrm{Aa}$ & $0.260 \mathrm{aBC}$ & $2.211 \mathrm{bB}$ & $3.860 \mathrm{aA}$ & $0.362 \mathrm{bC}$ & $0.507 \mathrm{aB}$ \\
\hline CV (\%) & \multicolumn{2}{|c|}{17.22} & \multicolumn{2}{|c|}{23.02} & \multicolumn{2}{|c|}{16.17} & \multicolumn{2}{|c|}{10.01} \\
\hline
\end{tabular}

EC - Electrical conductivity; MS - Mixture of salts. Same lowercase letters between water sources, upper case among EC treatments did not differ from each other, by Tukey's test, at 0,05 probability 

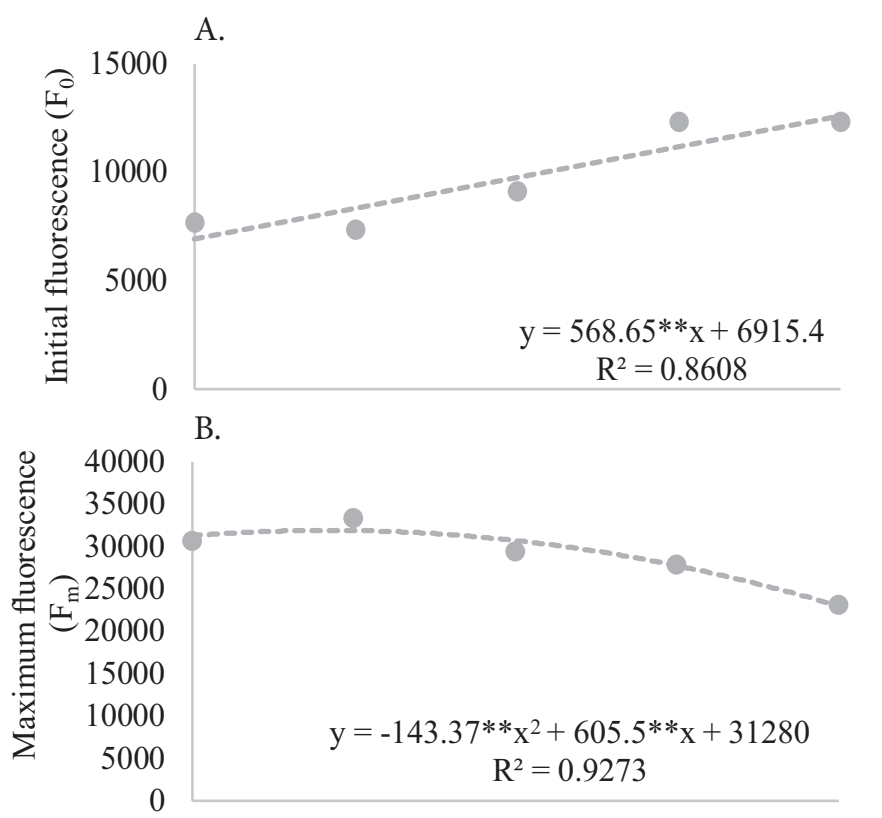

C.

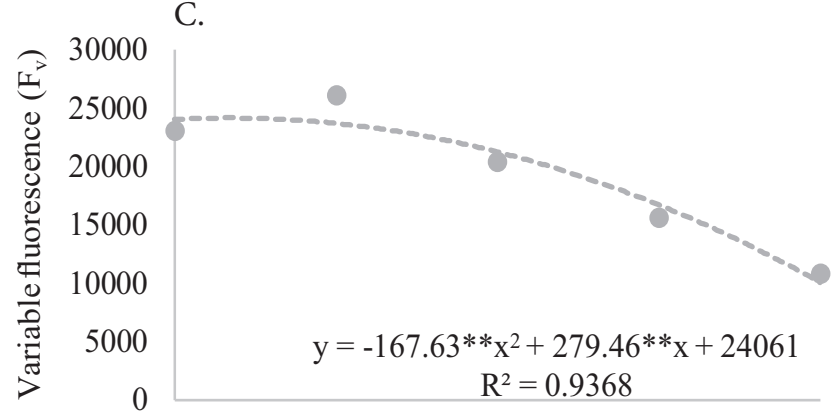

D.

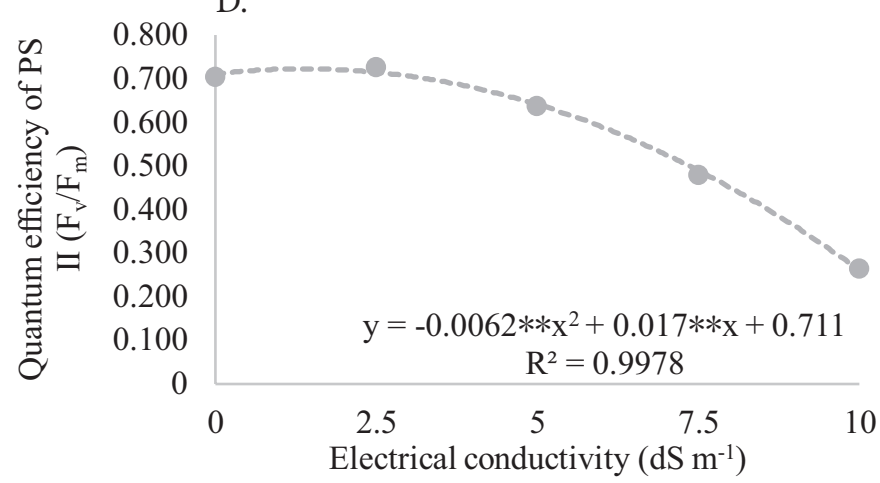

Figure 1. Parameters of chlorophyll a fluorescence emissions in saccharine sorghum plants under abiotic stress conditions at 60 days after sowing (DAS). Initial fluorescence - $F_{0}(A)$; maximum fluorescence - $F_{m}(B)$; variable fluorescence $-F_{v}(C)$; quantum efficiency of photosystem II - $F_{v} / F_{m}(D)$

photosystem II (PSII) is fully oxidized and the reaction center (P680) is open, indicating the activation of the photochemical reactions (Baker \& Rosenqvst, 2004). In a study with sorghum and salinity, the emission of the initial fluorescence $\left(\mathrm{F}_{0}\right)$ increased with an increase in the electrical conductivity (Nabati et al., 2013). The increase in $\mathrm{F}_{0}$ in plants subjected to some type of stress may be related to the increase in leaf thickness (Munns \& Tester, 2008) due to lipid peroxidation by reactive oxygen species (Yamane et al., 2008).

The $\mathrm{F}_{\mathrm{m}}$ and $\mathrm{F}_{\mathrm{v}}$ presented with a significant differences $(\mathrm{p}<$ 0.01 ) in electrical conductivity levels. With the increase in the electrical conductivity of the irrigation water, the emission of both $\mathrm{F}_{\mathrm{m}}$ and $\mathrm{F}_{\mathrm{v}}$ decreased by 26.48 and $58.05 \%$, respectively, when the EC of $10 \mathrm{dS} \mathrm{m}^{-1}$ was compared to the control (Figures $1 \mathrm{~B}$ and $\mathrm{C})$.

The maximum fluorescence emission represents the maximum intensity of the fluorescence, when practically all the quinone is reduced and the reaction centers reach the maximum capacity for photochemical reactions (Baker \& Rosenqvist, 2004; Silva et al., 2015). According to Nabati et al. (2013), sorghum plants submitted to irrigation with increasing levels of electrical conductivity $\left(5.2 ; 10.5 ; 23.1 \mathrm{dS} \mathrm{m}^{-1}\right)$ presented a reduction in $\mathrm{F}_{\mathrm{m}}$ with the elevation of salinity. They also reported that the decrease in the maximum fluorescence was related to the photoinhibition caused by saline stress.

The quantum efficiency of PSII $\left(\mathrm{F}_{\mathrm{v}} / \mathrm{F}_{\mathrm{m}}\right)$ presented significant difference only in the electrical conductivity levels. The saccharine sorghum plants reduced the quantum efficiency of PSII with elevated salinity levels (Figure 1D), showing reductions from the $\mathrm{EC}$ of $5 \mathrm{dS} \mathrm{m}^{-1}$, reaching values $63.3 \%$

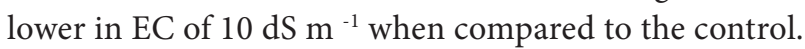

Coelho et al. (2011) studied sorghum plants subjected to irrigation with saline solution with $15 \mathrm{~g} \mathrm{~L}^{-1} \mathrm{NaCl}$ concentration, and they observed reductions of $35 \%$ in the quantum efficiency of PSII. According to Tezara et al. (2005), plants that present an $\mathrm{F}_{\mathrm{v}} / \mathrm{F}_{\mathrm{m}}$ below 0.8 are subjected to stressful conditions and a reduction in the maximum quantum efficiency of PSII, a situation similar to the plants of the present study that presented with $\mathrm{F}_{\mathrm{v}} / \mathrm{F}_{\mathrm{m}}$ values of below $0.728\left(2.5 \mathrm{dS} \mathrm{m}^{-1}\right)$ to $0.266\left(10 \mathrm{dS} \mathrm{m}^{-1}\right)$. In stress-prone situations, plants do not present changes in the primary photochemistry of PSII, but a reduction in the quantum efficiency of electron transport is observed (Lu \& Zhang, 1998).

As the EC levels increased, the electron transport flux decreased progressively (Figure 2A) and presented a statistical difference. The greatest reduction compared to the control $\left(0 \mathrm{dS} \mathrm{m}^{-1}\right)$ occurred for the EC of $10 \mathrm{dS} \mathrm{m}^{-1}$ (45.70\%). The electrical conductivity of $2.5,5$, and $7.5 \mathrm{dS} \mathrm{m}^{-1}$ decreased by $2.28,10.66$, and $25.13 \%$, respectively.

With increasing levels of saline concentration $(0,50,100$, and $250 \mathrm{mM}$ ), reductions in the electron transport rate of 20 and $29 \%$ were observed for two sorghum varieties, according to Netondo et al. (2004). This reduction in electron transfer rates can be attributed to the ions that cause deleterious effects on the thylakoid membranes, disrupting the electron transport in the lipid-protein bilayer, and damaging the activity of the complex (Ambede et al., 2012).

The quantum of energy dissipation by the reaction center showed a significant effect $(p<0.01)$ on the electrical conductivity levels of the irrigation water. At 60 DAS, it was observed that the energy dissipated by the reaction center increased with the increasing salinity levels (Figure $2 \mathrm{~B}$ ). The

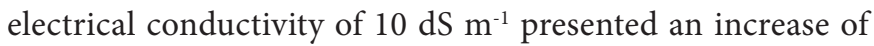
$179.29 \%$ in relation to the electrical conductivity of $0 \mathrm{dS} \mathrm{m}^{-1}$ group (Figure 2B). According to Zegada-Lizarazu et al. (2015), the dissipation of excess energy is a mechanism of release and regulation of PSII, allowing the closure of the reaction centers and preserving the cycles of xanthophyll and lutein. 


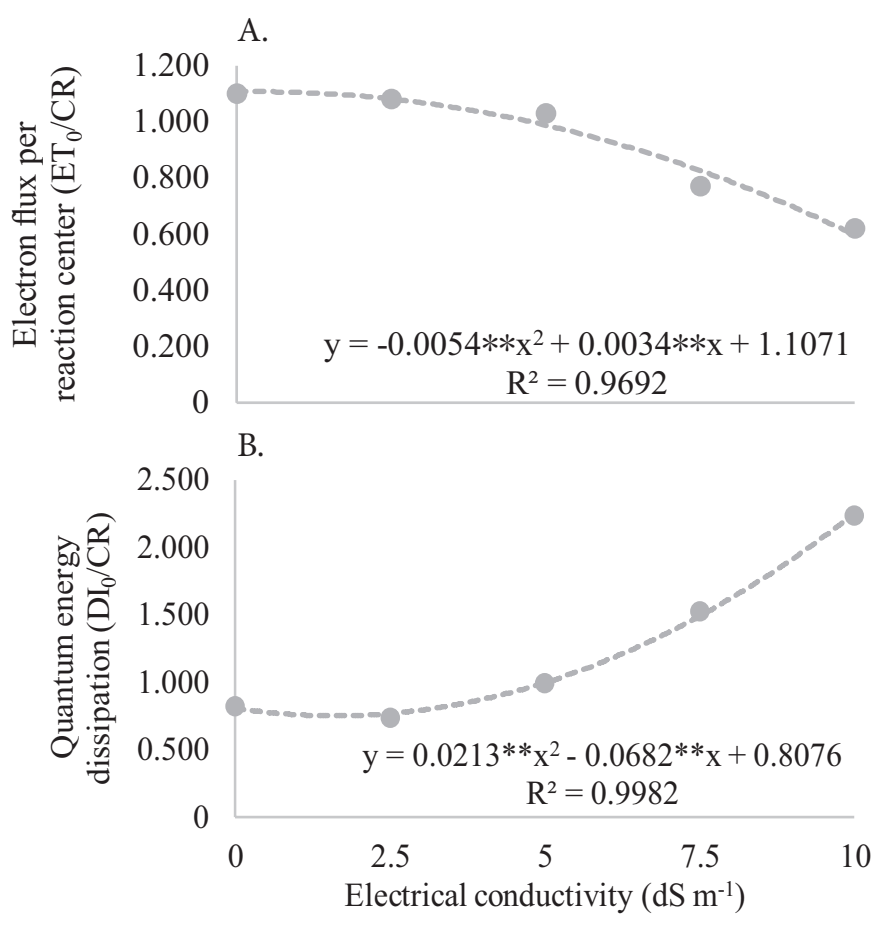

Figure 2. Electron flux per reaction center in sorghum plants submitted to irrigation with saline solutions at 60 days after sowing (DAS) (A); Energy dissipated by reaction center in sorghum plants under abiotic stress conditions at 60 DAS (B)

The quantum yield for heat dissipation $\left(\varphi \mathrm{D}_{0}\right)$ showed significant interaction between salt sources and levels of electrical conductivity $(\mathrm{p}<0.05)$. With the increase in salinity, it was observed that for both salt sources there was an increase in $\varphi \mathrm{D}_{0}$ (Figure 3), except for the EC of $2.5 \mathrm{dS} \mathrm{m} \mathrm{m}^{-1}$, which presented reductions of $17.29 \%(\mathrm{NaCl})$ and $10.82 \%$ (salt mix). The highest increments were observed for EC $10 \mathrm{dSm}^{-1}(\mathrm{NaCl})$ and in EC $7.5 \mathrm{dS} \mathrm{m}^{-1}$ (salt mix), corresponding to 152.96 and $125.50 \%$, respectively.

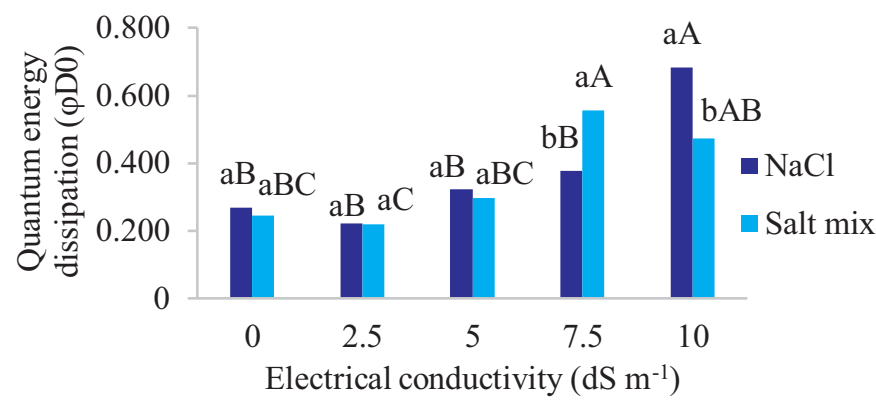

The same lowercase letters between water sources and upper case letters between treatments did not differ from each other, by Tukey's test $(p<0.05)$

Figure 3. Quantum yield for heat dissipation in sorghum plants at 60 says after sowing (DAS) irrigated with saline solutions with increasing electrical conductivity levels

\section{Conclusions}

1. High salinity causes the degradation of photosynthetic pigments, both chlorophyll $\mathrm{a}$ and $\mathrm{b}$ and carotenoids in sorghum plants, in response to severe abiotic stress.

2. The increase in the electrical conductivity of the saline solutions used in the irrigation of the plants negatively affected the quantum efficiency of photosystem II and the electron flow per reaction center, thus modifying the emission of chlorophyll a fluorescence, implying severe damage to the photosynthetic apparatus of the sorghum plants.

\section{Literature Cited}

Ambede, J. G.; Netondo, G. W.; Mwai, G. N.; Musyimi, D. M. $\mathrm{NaCl}$ salinity affects germination, growth, physiology, and biochemistry of bambara groundnut. Brazilian Journal of Plant Physiology, v.24, p.151-160, 2012. https://doi.org/10.1590/S167704202012000300002

Ashraf, M.; Harris, P. J. C. Photosynthesis under stressful environments: An overview. Photosynthetica, v.51, p.601-639, 2013. https://doi. org/10.1007/s11099-013-0021-6

Baker, N. R.; Rosenqvist, E. Applications of chlorophyll fluorescence can improve crop production strategies: An examination of future possibilities. Journal of Experimental Botany, v.55, p.1607-1621, 2004. https://doi.org/10.1093/jxb/erh196

Barreto, T. H. L.; Souza, R. P. de; Pacheco, C. M.; Walter, L. S.; Soares, J. G.; Oliveira, L. dos S. O.; Nogueira, R. J. M. C. Efeito do estresse salino sobre a concentração de pigmentos em duas variedades de cana-de-açúcar. In: Jornada de Ensino, Pesquisa e Extensão JEPEX, 8, 2013, Recife. Anais... Recife: UFRPE, 2013.

Cancellier, E. L.; Barros, H. B.; Kischel, E.; Gonzaga, L. A. de M.; Brandão, D. R.; Fidelis, R. R. Eficiência agronômica no uso de nitrogênio mineral por cultivares de arroz de terras altas. Revista Brasileira de Ciências Agrarias, v.6, p.650-656, 2011. https://doi. org/10.5039/agraria.v6i4a1420

Coelho, R.; Castanheira, N.; Santos, F. L.; Pereira, D. G.; Gonçalves, M. C. Efeitos da salinidade e fertilização azotada nos parâmetros hídricos e fotossintéticos na fase inicial de desenvolvimento de Sorgo sacarino (Sorghum bicolor L. Moench). In: Congresso Ibérico de Agroengenharia, 4, 2011, Évora. Anais... Évora: Universidade de Évora, 2011.

Deinlein, U.; Stephan, A. B.; Harie, T.; Luo, W.; Xu, G.; Schroeder, J. I. Plant salt-tolerance mechanisms. Trends in Plant Science, v.19, p.371-379, 2014. https://doi.org/10.1016/j.tplants.2014.02.001

EMBRAPA - Empresa Brasileira de Pesquisa Agropecuária. Manual de métodos de análise de solo. Rio de Janeiro: Embrapa Solos, 1997. 212p.

EMBRAPA - Empresa Brasileira de Pesquisa Agropecuária. Sistema Brasileiro de Classificação de solos. Rio de Janeiro: Embrapa Solos, 2013. 353p.

Lacerda, C. F. de; Cambraia, J.; Oliva, M. A.; Ruiz, H. A.; Prisco, J. T. Solute accumulation and distribution during shoot and leaf development in two sorghum genotypes under salt stress. Environmental and Experimental Botany, v.49, p.107-120, 2003. https://doi.org/10.1016/S0098-8472(02)00064-3

Lichtenthaler, H. K.; Buschmann, C. Chlorophylls and carotenoids: Measurement and characterization by UV-VIS spectroscopy. Current Protocols in Food Analytical Chemistry, v.1, p.1-8, 2001. https://doi.org/10.1002/0471142913.faf0403s01

$\mathrm{Lu}, \mathrm{C}$.; Zhang, J. Thermostability of photosystem II is increased in salt-stressed sorghum. Functional Plant Biology, v.25, p.317-324, 1998. https://doi.org/10.1071/PP97138

Maxwell, K.; Johnson, G. N. Chlorophyll fluorescence: A practical guide. Journal of Experimental Botany, v.51, p.659-668, 2000. https://doi.org/10.1093/jexbot/51.345.659 
Melo, H. F.; Souza, E. R. D.; Cunha, J. C. Fluorescence of chlorophyll a and photosynthetic pigments in Atriplex nummularia under abiotic stresses. Revista Brasileira de Engenharia Agrícola e Ambiental, v.21, p. 232-237, 2017a. https://doi.org/10.1590/18071929/agriambi.v21n4p232-237

Melo, H. F.; Souza, E. R. D.; Duarte, H. H.; Cunha, J. C.; Santos, H. R. Gas exchange and photosynthetic pigments in bell pepper irrigated with saline water. Revista Brasileira de Engenharia Agrícola e Ambiental, v.21, p.38-43, 2017b. https://doi. org/10.1590/1807-1929/agriambi.v21n1p38-43

Munns, R.; Tester, M. Mechanisms of salinity tolerance. Annual Review of Plant Biology, v.59, p.651-681, 2008. https://doi. org/10.1146/annurev.arplant.59.032607.092911

Nabati, J.; Kafi, M.; Mehrjerdi, M. Z. Effect of salinity and silicon application on photosynthetic characteristics of sorghum (Sorghum bicolor L.). International Journal of Agricultural Sciences, v.3, p.483-492, 2013.

Netondo, G. W.; Onyango, J. C.; Beck, E. Sorghum and salinity: I. Response of growth, water relations, and ion accumulation to $\mathrm{NaCl}$ salinity. Crop Science, v.44, p.797-805, 2004. https://doi. org/10.2135/cropsci2004.7970

Neves, L. A. S. das; Spat, C. Concentração de clorofila e de prolina em genótipos de arroz submetidos à salinidade. Unimontes Científica, v.15, p.1-10, 2013.

Richards, L. A. Diagnosis and improvement of saline and alkali soils. Washington: United States Department of Agriculture, 1954. 160p. Agriculture Handbook, 60
Silva, F. G. da; Dutra, W. F.; Dutra, A. F.; Oliveira, I. M. de; Filgueiras, L.; Melo, A. S. de. Gas exchange and chlorophyll fluorescence of eggplant grown under different irrigation depths. Revista Brasileira de Engenharia Agrícola e Ambiental, v.19, p.946-952, 2015.

Tavakkoli, E.; Fatehi, F.; Coventry, S.; Rengasamy, P.; McDonald, G. K. Additive effects of $\mathrm{Na}^{+}$and $\mathrm{Cl}^{-}$ions on barley growth under salinity stress. Journal of Experimental Botany, v.62, p.2189-2203, 2011. https://doi.org/10.1093/jxb/erq422

Tezara, W.; Marín, O.; Rengifo, E.; Martínez, D.; Herrera, A. Photosynthesis and photoinhibition in two xerophytic shrubs during drought. Photosynthetica, v.43, p.37-45, 2005. https://doi. org/10.1007/s11099-005-7045-5

Viana, M.; Queiroz, C. G. S.; Durães, F. O. M.; Souza, J.; Albuquerque, P. E. P.; Machado, R. A. F. Alterações em pigmentos e danos em membranas de milho submetido ao déficit hídrico. In: Congresso Nacional de Milho e Sorgo, 24, 2002, Florianópolis. Anais... Sete Lagoas: ABMS/Embrapa Milho e Sorgo; Florianópolis: Epagri, 2002. Yamaguchi, T.; Blumwald, E. Developing salt-tolerant crop plants: Challenges and opportunities. Trends in Plant Science, v.10, p.615-620, 2005. https://doi.org/10.1016/j.tplants.2005.10.002

Yamane, K.; Kawasaki, M.; Taniguchi, M.; Miyake, H. Correlation between chloroplast ultrastructure and chlorophyll fluorescence characteristics in the leaves of rice (Oryza sativa L.) grown under salinity. Plant Production Science, v.11, p.139-145, 2008. https:// doi.org/10.1626/pps.11.139

Zegada-Lizarazu, W.; Luna, D. F.; Monti, A. Photosynthetic acclimation of sweet sorghum under progressive water stress. Industrial Crops and Products, v.66, p.216-219, 2015. https://doi. org/10.1016/j.indcrop.2014.12.045 